\title{
PENGARUH CONVENIENCE, EASE OF INFORMATION SEARCH, TRANSACTION, INFORMATION CREDIBILITY, PRICE AND SAFETY TERHADAP ONLINE HOTEL REPURCHASE INTENTION GENERASI Z PADA ONLINE TRAVEL AGENT (OTA)
}

\author{
Angelia Novianti ${ }^{1}$, Felia Irawan ${ }^{2}$, Agung Harianto ${ }^{3 *}$ \\ ${ }^{1,2,3}$ Program Studi Manajemen Perhotelan, Universitas Kristen Petra \\ Jl. Siwalankerto 121-131, Surabaya, 60236, Indonesia \\ Email: ${ }^{2}$ angelianovianti21@gmail.com; ${ }^{2}$ feliairawann@gmail.com; ${ }^{3}$ agung.harianto@petra.ac.id \\ *Penulis korespondensi
}

\begin{abstract}
Abstrak: Tujuan penelitian ini untuk mengetahui apakah convenience, ease of information search, transaction, information credibility, price and safety berpengaruh terhadap online hotel repurchase intention Generasi Z pada OTA. Sampel yang digunakan dalam penelitian ini sebanyak 154 responden. Hasil dari penelitian menunjukkan bahwa convenience, ease of information search, information credibility, price dan safety berpengaruh positif dan signifikan terhadap online hotel repurchase intention generasi $\mathrm{Z}$, sedangkan transaction berpengaruh negatif dan tidak signifikan terhadap online hotel repurchase intention generasi Z. Variabel safety menjadi faktor yang paling dominan dalam mempengaruhi online hotel repurchase intention generasi $Z$ pada OTA.
\end{abstract}

Kata kunci: Convenience, ease of information search, information credibility, online hotel repurchase intention, price, safety, transaction.

\begin{abstract}
The aim of this research is to know whether convenience, ease of information search, transaction, information credibility, price and safety affect Generation Z's online hotel repurchase intention on OTA. The sample used in this study were 154 respondents. The results showed that convenience, ease of information search information credibility, price and safety had a positive and significant effect on online hotel repurchase intention generation $Z$, whereas transaction had a negative and not significant effect on online hotel repurchase intention generation Z. Safety was the most dominant factor that affect Generation Z's online hotel repurchase intention on OTA.
\end{abstract}

Keywords: Convenience, ease of information search, information credibility, online hotel repurchase intention, price, safety, transaction.

\section{PENDAHULUAN}

Perkembangan teknologi pada era globalisasi ini semakin berkembang pesat sehingga banyak masyarakat yang mulai bergantung pada internet. Peran information technology (IT) dan internet dianggap akan menyediakan kesempatan yang bagus untuk penjualan ke depannya (Dev \& Olsen, 2000). Teknologi informasi \& komputer, khususnya internet, telah meru bah keadaan sosial ekonomi pada pariwisata \& akan menimbulkan perubahan yang lebih besar.

Internet dianggap sebagai distribusi alternatif yang dapat kompatibel dengan saluran yang ada (Rayman-Bacchus \& Molina, 2001). Indonesia berada di peringkat ke-6 di dunia sebagai pengguna internet terbanyak, sehingga dengan semakin banyaknya pengguna internet di yang ada dan membuka peluang bisnis-bisnis online.

Menurut hasil survey Dailysocial, Traveloka meraih peringkat pertama sendiri merupakan perusahaan perjalanan wisata online terkemuka di Asia Tenggara yang menyediakan berbagai dalam satu platform.
Traveloka menjalin kerjasama dengan beragam hotel, apartement, guesthouse, homestay, villa, dan resort yang menjadikan Traveloka memiliki inventaris akomodasi langsung terbesar. Aplikasi traveloka sendiri telah diunduh sebanyak lebih dari 30 juta kali yang membuat traveloka menjadi travel booking app terpopuler di Indonesia. Dari hasil survey yang dilakukan oleh Avara Research yang diikuti oleh 1204 responden dari usia 17 hingga 39 tahun, survey menemukan bahwa traveloka merupakan aplikasi travelling yang paling banyak digunakan oleh generasi millennial terutama oleh kaum generasi $\mathrm{Z}$, dimana traveloka digunakan oleh $79 \%$ dari jumlah responden.

Generasi Z yang dikenal dengan sebutan Digital Natives, karena generasi $\mathrm{Z}$ tumbuh dan berkembang dimana era media elektronik dan teknologi digital bertumbuh sangat cepat. Generasi $Z$ yang juga disebut sebagai Digital Tourist, dimana generasi ini sangat bergantung dan sering menggunakan teknologi seperti gadget, sosial media \& internet (rata-rata penggunaan 16 jam / hari) dan salah satunya yaitu menggunakan 
layanan aplikasi OTA (Online Travel Agent). Generasi ini menggunakan internet \& web untuk menemukan informasi yang diperlukan untuk membuat keputusan pembelian dan membuat reservasi.

Menurut penelitian yang diadakan oleh Kim \& Kim yang berjudul Factors affecting online hotel reservation intention between online \& non online customers, dimana penelitian tersebut mencari hubungan 6 variabel yaitu Convenience, Ease of information search, Transaction, Information Credibility, Price, Safety terhadap online hotel reservation intention. Peneliti menganggap bahwa keenam faktor tersebut relevan dengan penelitian yang akan peneliti lakukan. Penelitian ini dilakukan sebagai lanjutan dari penelitian terdahulunya yaitu Factors affecting online hotel reservation intention between online \& non online customers (Kim \& Kim, 2004). Oleh karena itu, peneliti ingin mengetahui tentang pengaruh Convenience, Ease of information search, Transaction, Information Credibility, Price, Safety terhadap Online Hotel Repurchase Intention generasi $\mathrm{Z}$ pada Traveloka.

\section{LANDASAN TEORI}

\section{Generasi Z}

Generasi $Z$ yang pada umumnya disingkat dengan sebutan Gen $\mathrm{Z}$ juga diketahui sebagai iGenaration, yang merupakan generasi setelah Generasi Millenial atau Generasi Y.

Menurut Taspcott (2008), Generasi Z merupakan sekelompok individu yang lahir pada tahun 1995 sampai 2012. Generasi $Z$ atau yang kemudian banyak dikenal dengan generasi digital merupakan generasi muda yang tumbuh dan berkembang dengan sebuah ketergantungan yang besar pada teknologi digital. Bagi generasi $\mathrm{Z}$ informasi dan teknologi adalah hal yang sudah menjadi bagian dari kehidupan generasi $\mathrm{Z}$, karena generasi tersebut lahir dimana akses terhadap informasi, khususnya internet sudah menjadi budaya global.

\section{Karakteristik Generasi Z}

Karakterikstik generasi $\mathrm{Z}$ yaitu sangat berhubungan erat dengan digital dan teknologi informasi karena Generasi Z lahir pada saat dunia digital mulai berkembang pesat di dunia. Generasi ini sangat mahir dalam menggunakan segala macam gadget yang ada, serta menggunakan teknologi dalam keseluruhan aspek dalam sehari-hari.
Generasi $\mathrm{Z}$ cenderung menyukai hal yang praktis dan berperilaku instan. Kaum generasi $Z$ tidak menyukai meluangkan waktu yang berlama-lama untuk proses panjang dalam mencermati suatu masalah yang sedang dihadapi. Hal ini disebabkan anak-anak generasi $\mathrm{Z}$ ini lahir dalam dunia yang serba instan.

\section{Technology Acceptance Model (TAM)}

Technology Acceptance Model (TAM) yang dikembangkan oleh Davis (1989) diadopsi berdasarkan Theory of Reasoned Action (TRA), yang menjelaskan penerimaan teknologi informasi untuk berbagai tugas. TRA itu sendiri merupakan teori tentang tindakan dan persepsi individu terhadap suatu hal guna menentukan sikap serta minat dalam berperilaku. Davis et al. (1989) mengidentifikasi perceived usefulness serta perceived ease of use sebagai faktor penentu dasar dalam penerimaan sistem informasi. Perceived usefulness dan perceived ease of use mempengaruhi sikap individu terhadap suatu teknologi. Perceived ease of use mempengaruhi sikap dengan dua cara yaitu self-efficiency dan instrumentality (Davis et al., 1989) sehingga semakin sederhana interaksi dengan suatu sistem, semakin besar minat individu terhadap efisiensi dan kontrol (Bandura, 1982). Seperti yang ditunjukkan oleh Kim et al. (2008), jika website mudah dipahami dan dipelajari untuk dioperasikan, pengguna internet akan lebih mudah merasakan convenience, usefulness \& develop positive attitude.

\section{Perceived Relative Advantage}

Perceived Relative Advantage didefinisikan sebagai sejauh mana online travel shopping menyediakan manfaat bagi konsumen misalnya kenyamanan (convenience) (Kim \& Kim, 2004;), harga lebih rendah ( lower price) (Kim \& Kim, 2004; Kim et al., 2006), hemat waktu ( time saving) (Heung, 2003; Wong \& Law, 2005) dan hubungan dengan orang yang memiliki minat yang sama. Oleh karena itu, Perceived Relative Advantage dari online travel shopping dikonseptualisasikan sebagai suatu bentuk multidimensi yang mencakup segala manfaat belanja online ini.

\section{Convenience}

Convenience merupakan istilah yang merujuk pada preferensi umum seseorang terhadap barang dan layanan yang nyaman (Yale \& Venkatesh, 1986). 
Sebagai contoh, Morganosky (1986) mendefinisikan pelanggan yang convenience-oriented sebagai orang yang berusaha untuk menyelesaikan tugas dalam waktu yang singkat dengan pengeluaran energi manusia paling sedikit. Convenience diidentifikasi sebagai salah satu dari 3 alasan utama (convenience, price comparison and lower price) mengapa pengguna internet membeli produk perjalanan wisata secara online (Duman, 2017).

\section{Ease of Information Search}

Beatty \& Smith (1987) mendefinisikan information search sebagai tingkat perhatian, persepsi dan upaya yang diarahkan untuk memperoleh data atau informasi yang terkait dengan pembelian spesifik yang sedang dipertimbangkan. Sedangkan dalam konteks ini Ease Of Information Search dapat diartikan sebagai kemudahan dalam mencari informasi. Penelitian Kim dan Kim (2004) menunjukkan bahwa pelanggan online menganggap kemudahan pencarian informasi dan transaksi menjadi faktor yang lebih penting dari pada harga.

\section{Transaction}

Ahn \& Park (2004) mendefinisikan transaksi sebagai proses kolaboratif pertukaran informasi untuk perdagangan barang atau melakukan kegiatan yang berhubungan dengan perdagangan. Transaksi online didefinisikan sebagai perubahan dalam informasi pertukaran atau perubahan dalam bagian dari informasi yang berubah karena diberikan tujuan transaksi. Menurut hasil penelitian Hung (2011), ditemukan bahwa pengguna OTA sangat mementingkan faktorfaktor transaksi yaitu kemampuan untuk melakukan transaksi online secara cepat dan efisien.

Dari hasil penelitian terdahulu (Kim \& Kim, 2004) menemukan bahwa dalam fitur transaksi OTA, pemesanan harus dirancang dengan sederhana dan jelas serta meningkatkan kredibilitas dan keandalan transaksi online juga dapat membangun sistem reservasi yang cepat, stabil dan memberikan informasi yang akurat.

\section{Information Credibility}

Information Credibility didefinisikan sebagai kepercayaan suatu sumber dan sebagian besar bersandar pada persepsi kepercayaan dan keahlian sumber informasi sebagaimana diartikan oleh penerima informasi (Hovland et al., 1953). Penelitian di bidang ilmu informasi telah berfokus pada information credibility dimana penekanannya adalah pada kepercayaan ter- hadap messages daripada speakers (Metzger \& Flanagin, 2013). Menurut Srikandi (2008), karena beberapa lapis sumber, pengguna media mempertimbangkan kredibilitas sumber dan juga kredibilitas informasi.

Price

Price atau harga adalah jumlah uang yang ditukar pelanggan dalam hal layanan, produk, nilai yang diterima (Kotler \& Armstrong, 2010). Dalam industri perhotelan, harga yang wajar akan menghasilkan nilai persepsi pelanggan yang lebih besar dan meningkatkan niat pembelian konsumen. Duman\&Mattila (2005) mengidentifikasi harga sebagai faktor penting dari nilai yang dirasakan dalam layanan pariwisata. Oleh karena itu, dalam kisaran harga yang dapat diterima oleh pengguna, mengubah harga untuk kualitas yang diberikan dimana mengarah ke nilai persepsi yang lebih tinggi dan mengakibatkan ke minat yang lebih besar untuk membeli. Riset tentang belanja online menunjukkan bahwa adanya diskon harga memiliki efek positif pada niat beli konsumen.

\section{Safety}

Safety atau keamanan adalah salah satu masalah paling menantang dan kritis yang dihadapi oleh sistem online saat ini.

Menurut survey oleh Tyler Nelson Software Interactive (2002), masalah yang berhubungan dengan keamanan adalah hambatan utama yang mencegah pelanggan dari pembelian online, hal ini disebabkan karena tidak adanya kontak fisik secara langsung saat pembelian secara online sedangkan pelanggan sangat mementingkan keamanan transaksi saat melakukan pembelian online. Weber (1999) menunjukkan bahwa layanan online disampaikan dan dioperasikan dengan cara yang sangat handal dan dapat diandalkan untuk membangun kepercayaan dan menyampaikan kepercayaan kepada pelanggan.

\section{Minat Beli Ulang Online (Online Repurchase Intention)}

Minat beli ulang (repurchase intention) merupakan suatu komitmen konsumen yang terbentuk setelah konsumen melakukan pembelian suatu produk atau jasa. Online repurchase intention menurut Parastanti, Srikandi \& Kadarisman (2014) merupakan situasi dimana konsumen berkeinginan dan berniat untuk kembali membuat transaksi online. Srikandi (2014) menyatakan bahwa terdapat 4 indikator untuk mengukur minat beli ulang, yaitu:

1. Willingness to buy (Keinginan untuk membeli) 
Merupakan keinginan konsumen untuk membeli ulang suatu produk.

2. Tend to repurchase (Kecenderungan untuk membeli ulang) Menggambarkan perilaku konsumen yang cenderung akan membeli kembali suatu produk di masa depan.

3. More repurchase (Membeli ulang kembali)

Menggambarkan keinginan konsumen untuk terus membeli suatu produk.

4. Repurchase the same type of product (Membeli ulang produk yang sama)

Minat yang menggambarkan perilaku konsumen yang memiliki preferensi utama pada produk tersebut.

\section{HIPOTESIS PENELITIAN}

$\boldsymbol{H}_{1}$ : Convenience berpengaruh positif \& signifikan terhadap online hotel repurchase intention generasi $Z$ pada Traveloka.

$\boldsymbol{H}_{2}$ : Ease of Information Search berpengaruh positif \& signifikan terhadap online hotel repurchase intention generasi $\mathrm{Z}$ pada Traveloka.

$\boldsymbol{H}_{3}$ : Transaction berpengaruh positif \& signifikan terhadap online hotel repurchase intention generasi $Z$ pada Traveloka.

$\boldsymbol{H}_{4}$ : Information Credibility berpengaruh positif \& signifikan terhadap online hotel repurchase intention generasi $\mathrm{Z}$ pada Traveloka.

H5: Price berpengaruh positif \& signifikan terhadap online hotel repurchase intention generasi $\mathrm{Z}$ pada Traveloka.

$\boldsymbol{H}_{6}$ : Safety berpengaruh positif \& signifikan terhadap online hotel repurchase intention generasi $\mathrm{Z}$ pada Traveloka.

$\boldsymbol{H}_{7}$ : Diantara faktor convenience, ease of information search, transaction, information credibility, price, safety. Faktor yang paling dominan dalam mempengaruhi online hotel repurchase intention generasi $\mathrm{Z}$ pada Traveloka adalah convenience.

\section{METODE}

Jenis penelitian yang peneliti gunakan untuk melakukan penelitian ini adalah jenis penelitian eksplanatori, dengan menggunakan metode kuantitatif.

Penelitian eksploraif menurut Weber (1999, p.30) adalah penelitian yang tujuannya untuk menganalisis hubungan penelitian yang menggunakan statistik berupa angka-angka dan analisis yang digunakan untuk meneliti pada populasi atau sampel tertentu (Sugiyono, 2018, p.15).
Teknik yang digunakan dalam penelitian ini adalah purposive sampling yang termasuk dalam metode non probability sampling (Weber, 1999, p.133). Metode yang digunakan adalah purposive sampling yaitu teknik dimana sampling yang diambil berdasarkan antar variabel melalui uji hipotesis. Pendekatan kuantitatif adalah metode kriteria-kriteria yang telah ditentukan oleh peneliti yaitu:

1. Masyarakat Indonesia

2. Berumur 17-24 tahun

3. Sudah bekerja \& berpenghasilan sendiri

4. Pernah menggunakan aplikasi traveloka

5. Pernah membeli tiket hotel secara online dalam 6 bulan terakhir.

Indikator dalam penelitian ini dapat dilihat di tabel 1 operasional variable.

Tabel 1. Operasional Variabel

\begin{tabular}{|c|c|c|c|}
\hline Variabel & Indikator & Skala & No. Item \\
\hline \multirow[t]{2}{*}{ Convenience } & - Freedom from hassles & Likert & 1 \\
\hline & - 24 hours accessibility & Likert & 2 \\
\hline \multirow{8}{*}{$\begin{array}{l}\text { Ease of } \\
\text { information } \\
\text { search }\end{array}$} & - Easy payment procedures & Likert & 3 \\
\hline & $\begin{array}{l}\text { - Appropriate product/service } \\
\text { information }\end{array}$ & Likert & 4 \\
\hline & $\begin{array}{l}\text { - Real- time location of } \\
\text { available rooms }\end{array}$ & Likert & 5 \\
\hline & - Ease of comparing hotels & Likert & 6 \\
\hline & - Ease of contacting hotels & Likert & 7 \\
\hline & - Variety of choice & Likert & 8 \\
\hline & - Ease of finding what I want & Likert & 9 \\
\hline & $\begin{array}{l}\text { - Ease of acquiring hotel- } \\
\text { related information }\end{array}$ & Likert & 10 \\
\hline \multirow[t]{3}{*}{ Transaction } & $\begin{array}{l}\text { - Ease of understanding } \\
\text { policies }\end{array}$ & Likert & 11 \\
\hline & - Ease of placing orders & Likert & 12 \\
\hline & $\begin{array}{l}\text { - Credibility of online } \\
\text { transaction }\end{array}$ & Likert & 13 \\
\hline \multirow[t]{2}{*}{$\begin{array}{l}\text { Information } \\
\text { credibility }\end{array}$} & $\begin{array}{l}\text { - Reliability of provided } \\
\text { pictures }\end{array}$ & Likert & 14 \\
\hline & $\begin{array}{l}\text { - Reliability of products or } \\
\text { services information }\end{array}$ & Likert & 15 \\
\hline \multirow[t]{2}{*}{ Price } & $\begin{array}{l}\text { - Reduced purchase-related } \\
\text { costs }\end{array}$ & Likert & 16 \\
\hline & - Discounted price & Likert & 17 \\
\hline \multirow[t]{2}{*}{ Safety } & - Ease of canceling & Likert & 18 \\
\hline & $\begin{array}{l}\text { - Security of sensitive } \\
\text { information }\end{array}$ & Likert & 19 \\
\hline Minat Beli & - Willingness to buy & Likert & 20 \\
\hline \multirow[t]{3}{*}{ Ulang Online } & - Tend to repurchase & Likert & 21 \\
\hline & - More repurchase & Likert & 22 \\
\hline & $\begin{array}{l}\text { - Repurchase the same type of } \\
\text { product }\end{array}$ & Likert & 23 \\
\hline
\end{tabular}

HASIL DAN PEMBAHASAN Uji Validitas 
Berdasarkan hasil penelitian yang dilakukan pada 30 responden dengan tingkat signifikan 5\%, hasil pengujian validitas indikator dari semua variabel bebas maupun terikat menunjukkan bahwa semua variabel penelitian telah valid.

\section{Uji Reliabilitas}

Dari hasil uji reliabilitas yang telah dilakukan, terlihat nilai cronbach alpha untuk seluruh variabel baik variabel bebas maupun variabel terikat menunjukkan nilai yang lebih besar dari 0.60 yang berarti butir-butir pertanyaan dari seluruh variabel seluruhnya reliabel dan dapat digunakan dalam penelitian.

\section{Uji Normalitas}

Dalam penelitian ini, peneliti menggunakan uji statistik Kolmogorov-Smirnov Test. Hasil menunjukkan bahwa asymp sig adalah 0.2 lebih besar dari 0.05 maka dapat disimpulkan bahwa distribusi sampel berasal dari distribusi normal.

\section{Uji Multikolinearitas}

Hasil uji menunjukkan bahwa setiap nilai VIF pada semua variabel memiliki nilai lebih kecil dari 10 dan nilai toleransinya lebih besar dari 0.1 , dengan demikian dapat disimpulkan bahwa tidak terdapat masalah multikolinier, sehingga hasil pengujian dikatakan reliabel atau terpercaya.

\section{Uji Heteroskedastisitas}

Pada penelitian ini, peneliti menggunakan grafik scatterplot. Hasil uji menunjukkan bahwa titik-titik menyebar secara acak serta tersebar dengan baik di atas maupun di bawah angka 0 pada sumbu Y. Maka dapat disimpulkan bahwa tidak terjadi heteroskedastisitas pada model regresi penelitian ini.

\section{Uji Regresi Linear Berganda}

Hasil dari uji regresi linear berganda menunjukkan bahwa terdapat 5 variabel yang memiliki hubungan positif terhadap online hotel repurchase intention yaitu convenience, ease of information search, information credibility, price and safety. Sedangkan variabel transaction memiliki hubungan negatif terhadap online hotel repurchase intention. Variabel safety mendapat nilai tertinggi yaitu sebesar 0,439.

\section{Koefisien Determinasi Berganda}

Koefisien determinasi berganda $\left(\mathrm{R}^{2}\right)=0.459$ menunjukkan bahwa variabel Online Hotel Repurchase Intention $(\mathrm{Y})$ dipengaruhi oleh variabel convenience $\left(\mathrm{X}_{1}\right)$, ease of information search $\left(\mathrm{X}_{2}\right)$, transaction $\left(\mathrm{X}_{3}\right)$, information credibility $\left(\mathrm{X}_{4}\right)$, price $\left(\mathrm{X}_{5}\right)$ and safety $\left(\mathrm{X}_{6}\right)$ sebesar $45,9 \%$ dan 54,1\% dipengaruhi oleh faktor-faktor lainnya.

\section{Uji F}

Uji $F$ digunakan untuk menguji model regresi yang dapat menganalisis pengaruh variabel-variabel bebas secara simultan terhadap variabel terikat adalah signifikan. Hasil uji F menunjukkan bahwa keenam variabel secara simultan berpengaruh signifikan terhadap variabel Online Hotel Repurchase Intention (Y), dikarenakan tingkat signifikansi lebih rendah dari 0,05 dan nilai $\mathrm{F}$ hitung lebih besar dari $\mathrm{F}$ tabel. Berikut merupakan hasil dari uji F:

Tabel 2. Uji F

\begin{tabular}{llccccc}
\multicolumn{8}{c}{ ANOVA $^{\mathbf{b}}$} \\
\hline \multirow{2}{*}{ Model } & $\begin{array}{c}\text { Sum of } \\
\text { Squares }\end{array}$ & df & $\begin{array}{c}\text { Mean } \\
\text { Square }\end{array}$ & F & \multirow{2}{*}{ Sig. } \\
\hline 1 & Regression & 355.900 & 6 & 59.317 & 20.748 & $.000^{\mathrm{a}}$ \\
& Residual & 420.256 & 147 & 2.859 & & \\
\hline Total & 776.156 & 153 & & & \\
\hline
\end{tabular}

a. Predictors: (Constant), Safety (X6), Information Credibility (X4), Price (X5), Transaction (X3), Ease of Information Search (X2), Convenience $(\mathrm{X} 1)$

\section{Uji t}

Uji t digunakan untuk menguji satu arah dan dimaksudkan untuk mengetahui hubungan antara variabel-variabel bebas terhadap variabel terikat $(\mathrm{Y})$ secara parsial. Hasil perhitungan uji t menunjukkan bahwa secara parsial, variabel convenience, ease of information search \& safety adalah variabel yang memiliki pengaruh signifikan terhadap online hotel repurchase intention, sedangkan variabel transaction, information credibility \& price tidak memiliki pengaruh yang signifikan terhadap online hotel repurchase intention generasi $\mathrm{Z}$ pada Traveloka.

Berikut merupakan hasil dari uji t:

Tabel 3. Uji T

Coefficients ${ }^{\mathrm{a}}$

\begin{tabular}{|c|c|c|c|c|}
\hline \multirow[t]{2}{*}{ Model } & $\begin{array}{l}\text { Unstandardized } \\
\text { Coefficients }\end{array}$ & $\begin{array}{l}\text { Standardized } \\
\text { Coefficients }\end{array}$ & \multirow[t]{2}{*}{$\mathbf{t}$} & Sig. \\
\hline & B Std. Error & Beta & & \\
\hline
\end{tabular}




\begin{tabular}{llllll}
\hline 1 (Constant) & 1.904 & 1.452 & & 1.312 & 0.192 \\
Convenience (XI) & 0.271 & 0.105 & 0.269 & 2.589 & 0.011 \\
Ease ofInformation Search (X2) & 0.300 & 0.090 & 0.319 & 3.349 & 0.001 \\
Transaction (X3) & -0.156 & 0.138 & -0.110 & -1.132 & 0.259 \\
Information Credibility (X4) & 0.028 & 0.125 & 0.017 & 0.220 & 0.826 \\
Price (X5) & 0.122 & 0.129 & 0.076 & 0.946 & 0.346 \\
Safety (X6) & 0.439 & 0.137 & 0.240 & 3.208 & 0.002 \\
\hline
\end{tabular}

a. Dependent Variable: Online Hotel Repurcase Intention (Y)

\section{Pengaruh convenience terhadap online hotel repurchase intention}

Berdasarkan dari hasil pengolahan data menunjukkan bahwa terdapat pengaruh yang positif dan signifikan dari variabel convenience terhadap online hotel repurchase intention. Sehingga dapat terlihat bahwa convenience atau kenyamanan dari penggunaan aplikasi Traveloka akan berdampak pada minat beli ulang konsumen. Hasil dari penelitian ini sejalan dengan penelitian Kim \& Kim (2004) Tood (1997) yaitu convenience memiliki pengaruh yang positif dan signifikan terhadap minat reservasi online serta dalam sistem reservasi online, faktor yang harus ditonjolkan untuk menarik minat pengguna adalah convenience, price \& safety. Jika dilihat dari nilai mean indikator tertinggi pada variabel convenience, dapat dilihat bahwa responden merasa Traveloka memudahkan pengguna dengan dapat diakses selama 24 jam. Dari hasil mean setiap variabel juga diketahui bahwa variabel convenience mendapat nilai mean tertinggi. Dengan semakin mudahnya sistem pada online travel agent maka akan membuat pelanggan semakin nyaman sehingga membuat pelanggan akan melakukan pembelian ulang. convenience dianggap sebagai faktor yang paling penting dalam menentukan minat reservasi hotel secara online. Hal ini juga didukung dari hasil wawancara dengan 5 responden yang sudah berulang kali melakukan pemesanan hotel melalui Traveloka, yang menyatakan bahwa responden senang menggunakan aplikasi Traveloka dikarenakan dapat diakses dengan mudah, kapanpun dan dimanapun. Responden merasa dimudahkan dengan adanya Traveloka di tengah kesibukan kuliah dan pekerjaannya serta dapat melakukan pemesanan hotel dengan efisien.

\section{Pengaruh ease of information search terhadap online hotel repurchase intention}

Berdasarkan dari hasil penelitian dapat ditemukan bahwa terdapat pengaruh yang positif dan signifikan antara variabel bebas ease of information search terhadap variabel terikat yaitu online hotel repurchase intention. Dari hasil pengolahan data dapat terlihat bahwa kemudahan dalam pencarian informasi pada aplikasi Traveloka dapat mempengaruhi minat beli ulang konsumen. Hasil ini sejalan dengan pendapat Kim \& Kim (2004) yaitu dalam melakukan suatu pembelian online, informasi merupakan faktor yang penting. Hal ini didukung juga dengan jawaban responden yang menunjukkan nilai mean indikator tertinggi pada variabel ease of information search yaitu Traveloka menyajikan banyak macam pilihan layanan (contoh : hotel bintang 1-5, villa, guest house). Dengan adanya banyak pilihan \& informasi layanan yang disediakan oleh Traveloka maka konsumen akan merasa dipermudah dengan banyaknya pilihan layanan dalam satu aplikasi. Sehingga dengan semakin mudahnya pencarian informasi pada aplikasi Traveloka akan meningkatkan minat beli ulang konsumen. Berdasarkan hasil wawancara dengan 5 responden untuk mendukung hasil penelitian yang dilakukan, responden merasa dimudahkan karena dapat menemukan hotel yang sesuai dengan kebutuhan dan keinginannya pada saat itu dengan menggunakan aplikasi Traveloka.

\section{Pengaruh transaction terhadap online hotel repurchase intention}

Menurut hasil pengolahan data ditemukan bahwa variabel bebas transaction berpengaruh negatif \& tidak signifikan terhadap variabel terikat yaitu online hotel repurchase intention. Sehingga hipotesis peneliti yang menyatakan bahwa ada hubungan yang positif dan signifikan antara transaction terhadap online hotel repurchase intention ditolak. Hasil dari penelitian ini sejalan dengan penelitian Zarrad (2018) yang dalam penelitiannya menyatakan bahwa berdasarkan pengalaman pembelian melalui internet sebelumnya memiliki nilai korelasi yang negatif terhadap transaction. Hal ini menggambarkan bahwa responden merasa kurang puas dengan pengalamannya pada saat melakukan pembelian melalui internet. Hal ini juga menunjukkan bahwa semakin banyaknya pertukaran informasi yang disediakan oleh Traveloka tidak menyebabkan minat beli ulang generasi $\mathrm{Z}$ pada Traveloka. Peneliti melakukan wawancara dengan 5 responden untuk mendukung hasil penelitian yang dilakukan, responden merasa bahwa proses dalam melakukan pemesanan pada Traveloka masih agak rumit (adanya batas waktu untuk dalam melakukan pembayaran) dan kebijakan Traveloka seperti syarat dan ketentuan yang ada masih belum mudah untuk dipahami yang membuat responden enggan untuk melakukan pembelian ulang. 


\section{Pengaruh information credibility terhadap online hotel repurchase intention}

Menurut hasil pengolahan data ditemukan bahwa variabel bebas information credibility berpengaruh positif \& tidak signifikan terhadap variabel terikat yaitu online hotel repurchase intention. Sehingga hipotesis peneliti yang menyatakan bahwa ada hubungan yang positif dan signifikan antara information credibility terhadap online hotel repurchase intention ditolak. Hal ini sejalan dengan penelitian dari Kim \& Kim (2004) yang menyatakan bahwa information credibility tidak berpengaruh secara signifikan. Hal ini dapat diartikan bahwa information credibility tidak berpengaruh terhadap minat beli ulang hotel generasi $\mathrm{Z}$ pada Traveloka karena pengguna lebih mementingkan kenyamanan serta kemudahan dalam mencari informasi karena generasi $\mathrm{Z}$ lebih mementingkan keefisienan dan keefektifitasan. Dari hasil wawancara yang ada di lapangan, responden merasa bahwa gambar-gambar yang disediakan oleh Traveloka kurang dapat dipercaya yang terkadang tidak sesuai dengan kenyataannya.

\section{Pengaruh price terhadap online hotel repurchase intention}

Menurut hasil pengolahan data ditemukan bahwa variabel bebas price berpengaruh positif \& tidak signifikan terhadap variabel terikat yaitu online hotel repurchase intention. Sehingga hipotesis peneliti yang menyatakan bahwa ada hubungan yang positif dan signifikan antara price terhadap online hotel repurchase intention ditolak. Hasil penelitian ini didukung dengan hasil penelitian Kim \& Kim (2004) yang menyatakan bahwa semakin pelanggan mengenal online reservation, price menjadi faktor yang kurang penting dibanding dengan ease of information search dan transaction. Dalam penelitian ini, peneliti membahas mengenai online hotel repurchase intention sehingga berkaitan dengan pernyataan Kim \& Kim (2004) di atas dan price bukan menjadi faktor yang penting bagi pengguna yang sebelumnya sudah pernah menggunakan Traveloka. Didukung dengan hasil wawancara dengan salah satu responden yang sudah berulang kali melakukan pemesanan hotel di Traveloka merasa bahwa harga bukanlah suatu masalah yang penting dan diutamakan, karena di dalam kesibukan responden lebih mengutamakan pemesanan yang nyaman serta terpercaya. Peneliti menganggap bahwa hasil dari price ini dapat disebabkan karena potongan harga yang ditawarkan oleh Traveloka sulit untuk didapatkan karena terlalu banyak syarat dan ketentuan (minimum purchase, periode date, promo dengan kartu kredit tertentu) serta masih adanya dukungan orang tua di bidang financial.

\section{Pengaruh safety terhadap online hotel repurchase intention}

Menurut pengolahan data dapat ditemukan bahwa terdapat pengaruh yang positif dan signifikan antara variabel bebas safety terhadap variabel terikat yaitu online hotel repurchase intention. Dari hasil tersebut dapat terlihat bahwa keamanan yang dirasakan pengguna ketika menggunakan aplikasi Traveloka dapat mempengaruhi minat beli ulang konsumen. Hasil ini sejalan dengan penelitian Kim \& Kim (2004), Weber \& Roehl (1999) yaitu safety merupakan faktor yang signifikan baik bagi pembeli online maupun non-online serta informasi yang disediakan konsumen harus aman dari hackers dan basis data internal yang didapat dari transaksi harus digunakan dengan bijaksana. Hal ini juga didukung dengan jawaban responden yang menunjukkan nilai mean tertinggi yaitu Traveloka menjamin keamanan data pribadi pengguna. Dengan adanya jaminan keamanan yang disediakan pihak Traveloka dapat membuat membuat pengguna merasa aman, sehingga dapat meningkatkan minat beli ulang konsumen. Dengan pengalaman- pengalaman sebelumnya dari responden, responden merasa bahwa selama ini dalam melakukan pemesanan di Traveloka data pribadinya aman dan tetap terjaga.

Safety merupakan faktor yang paling dominan dalam mempengaruhi online hotel repurchase intention

Dari hasil penelitian yang telah dilakukan menunjukkan bahwa safety merupakan variabel yang paling dominan dalam mempengaruhi online hotel repurchase intention. Hal ini ditunjukkan dengan nilai $\beta$ yang diperoleh safety sebesar 0.439 merupakan nilai tertinggi jika dibandingkan dengan variabel bebas lainnya. Sehingga melalui hasil ini dapat dikatakan bahwa hipotesa peneliti yang menyatakan bahwa faktor yang paling dominan dalam mempengaruhi online hotel repurchase intention generasi $\mathrm{Z}$ pada Traveloka adalah convenience ditolak. Dari hasil jawaban responden ini dapat ditemukan bahwa jaminan keamanan merupakan faktor yang sangat penting dalam mempengaruhi minat beli ulang konsumen. Hal ini juga didukung dengan kenyataan di lapangan, pada jaman sekarang dengan semakin 
canggihnya teknologi yang ada membuat orang semakin peduli dengan masalah safety. Pada saat melakukan transaksi dengan menggunakan kartu kredit di internet, pelanggan beresiko kehilangan uang di rekening banknya karena informasi pribadi pelanggan dapat dicuri oleh hackers. Sesuai dengan penelitian Tsang et al. (2010), menyatakan bahwa masalah safety dalam membeli layanan perjalanan online disebut sebagai alasan utama untuk tidak melakukan transaksi perdagangan elektronik apapun. Sehingga hal ini menyebabkan safety menjadi hal yang paling diperhatikan dan paling dominan dalam mempengaruhi minat beli ulang.

\section{KESIMPULAN}

Berdasarkan hasil analisis penelitian yang telah dilakukan dengan variabel convenience, ease of information search, transaction, information credibility, price and safety serta online hotel repurchase intention dapat disimpulkan sebagai berikut:

1. Convenience berpengaruh positif dan signifikan terhadap online hotel repurchase intention generasi $\mathrm{Z}$ pada Traveloka.

2. Ease of information search berpengaruh positif dan signifikan terhadap online hotel repurchase intention generasi $\mathrm{Z}$ pada Traveloka.

3. Transaction berpengaruh negatif dan tidak signifikan terhadap online hotel repurchase intention generasi Z pada Traveloka.

4. Information credibility berpengaruh positif dan tidak signifikan terhadap online hotel repurchase intention generasi $\mathrm{Z}$ pada Traveloka.

5. Price berpengaruh positif dan tidak signifikan terhadap online hotel repurchase intention generasi $\mathrm{Z}$ pada Traveloka.

6. Safety berpengaruh positif dan signifikan terhadap online hotel repurchase intention generasi $\mathrm{Z}$ pada Traveloka.

7. Diantara Convenience, Ease of information search, Transaction, Information Credibility, Price dan Safety, Safety terbukti menjadi faktor yang paling dominan dalam mempengaruhi online hotel repurchase intention generasi $\mathrm{Z}$ pada Traveloka.

\section{DAFTAR PUSTAKA}

Ahn, H. J., \& Park, S. J. (2004). A Flexible Transaction Framework For Dynamic Collaboration Of Agents- With An Online Travel Application. International Journal of Cooperative Information Systems, 13(04), 487-
520 doi: 10.1142/ s0218843004001036 Bakar, A. R. A., \& Hashim, F. (2008).

The determinants of online hotel reservations among university staffs. Communications of the IBIMA, 4, 13-21 Retrieved from https://ibimapublishing.com/articles/CI BIMA/2008/785719/785719. Pdf.

Bandura A. (1982) Self-efficacy mechanism in human agency, Am. Psychologist, 37, 122-147.

Beatty, Sharon E. and Scott M. Smith. 1987. External Search Effort: An Investigation Across Several Product Categories. Journal of Consumer Research, 14(June): 83-95.

Davis, F. D. (1989). Perceived usefulness, perceived ease of use, and user acceptance of information technology. MIS Quarterly, 13(3), 319-340.

Dev, S.C., Olsen, M.D., 2000. Marketing challenges for the next decade. The Cornell Hotel and Restaurant Administration Quarterly, 41(1), 41-47.

Duman T., \& Mattila AS (2005) 'Peran pada faktorfaktor afektif pada dirasakan nilai cruise liburan', Manajemen Pariwisata, 26(3), 311-323, hal Science Direct, [Online]. DOI: 10.1016/j. tourman.2003.11.014 (Diakses: 22 Juli 2017).

Heung, V. C. S. (2003). Internet usage by international travellers: reasons and barriers. International Journal of Contemporary Hospitality Management, 15(7),370-378.

Hung, Y.-C., Yang, Y.-L., Yang, H.-E., \& Chuang, Y.-H. (2011). Factors affecting the adoption of e-commerce for the tourism industry in Taiwan. Asia Pacific Journal of Tourism Research, 16(1), 105-119.

Hovland, C.I., Janis, I.L., Kelley, J.J., 1953. Communication and Persuasion.Yale University Press, New Haven, CT.

Jarvenpaa, S.L., \& Todd, P.A. (1997). Consumer reactions to electronic shopping on the World Wide Web. International Journal of Electronic Commerce, 1(2), 59-88.

Kim, W. G., \& Kim, D. J. (2004). Factors affecting online hotel reservation intention between online and non-online customers. Internasional Journal of Hospitality Management, 23(4), 381395.

Kotler, P., \& Armstrong, G. (2010). Principles of marketing, New Jersey: Pearson Prentice Hall.

Metzger, M. J., \& Flanagin, A. J. (2013). Credibility and trust of information in online environments: The use of cognitive heuristics. Journal of Pragmatics, 59. doi: 10.1016/j.pragma.2013.07.012.

Morganosky, M. (1986). Cost versus Convenienceoriented Consumers: Demographic, Lifestyle, 
and Value Perspectives, Psychology and Marketing, 3(1): 35-46.

Parastanti, GP., Srikandi, K., dan Kadarisman, H. 2014. Pengaruh Prior Online Purchase experience Terhadap Trust dan Online Repurchase Intention. Jurnal Administrasi Bisnis (JAB), 16(1): 1-7.

Rayman-Bacchus, L., Molina, A., 2001. Internetbasedtourism services: business issues and trends. Futures, 33(7), 589-605.

Taspcott, Don (2008). Grown Up Digital: How the Net Generation is Changing Your World. McGraw-Hill.

Weber, K., \& Roehl, W.S. (1999). Profiling people searching for and purchasing travel products on the WorldWide Web. Journal of Travel Research, 37(3), 291-298.

Wong, J., \& Law, R. (2005). Analysing the intention to purchase on hotel websites: a study of travellers to Hong Kong. International Journal of Hospitality Management, 24(3), 311-329.
Yale, L., \& Venkatesh, A. (1986). Toward the Construct of Convenience in Consumer Research. Advances in Consumer Research, 13, 403-408.

Zarrad, H., \& Mohsen, D. (2012). Online purchasing intention: factors and effects. Internasional Business and Management, 4(1), 37-47. 